\title{
Copper Accumulation by Avicennia marina at Mangrove Eco-forest in Wonorejo, Surabaya
}

\author{
Harmin Sulistiyaning Titah ${ }^{1 *}$, Herman Pratikno ${ }^{2}$ \\ ${ }^{1}$ Department of Environmental Engineering, Faculty of Civil, Planning and Geo Engineering, Sepuluh \\ Nopember Institute of Technology, Keputih, Sukolilo, 60111 Surabaya, Indonesia \\ ${ }^{2}$ Department of Ocean Engineering, Faculty of Marine Technology, Sepuluh Nopember \\ Institute of Technology, Keputih, Sukolilo, 60111 Surabaya, Indonesia
}

\begin{abstract}
Large quantities of wastewater from industries and households were released to Wonorejo river in Surabaya East Coast area. The concentration of $\mathrm{Cu}$ at the Wonorejo Estuary reached $3.186 \mathrm{mg} / \mathrm{L}$ at brackish water in 2009 One of the inorganic pollutants that can be removed by mangrove is copper $(\mathrm{Cu})$. The purpose of this research was to determine the potency of $\mathrm{Cu}$ accumulation by Avicennia marina that was grown for ten years at Wonorejo Estuary. The sampling activities were conducted using a transect quadrat sampling method with a $10 \times 10 \mathrm{~m}$ dimension. There were ten points of location sampling, the sediment and root of $A$. marina samples were collected in those location sampling. All samples of sediment and root were extracted before those samples were analyzed using an atomic absorption spectrophotometer (AAS). The calculation of the Bioconcentration Factor (BCF) was conducted using a equation formulation. The results showed that concentration $\mathrm{Cu}$ in sediment was 27 $\mathrm{mg} / \mathrm{kg}$ until to $150 \mathrm{mg} / \mathrm{kg}$. The $\mathrm{Cu}$ accumulation by roots of $A$. marina reached $53 \mathrm{mg} / \mathrm{kg}$ until to $128 \mathrm{mg} / \mathrm{kg}$. The BCF value in $A$. marina were 0.91 to 3.22 In conclusion, A. marina showed potential as a hyperaccumulator for $\mathrm{Cu}$.
\end{abstract}

Keywords. Bioconcentration, $\mathrm{Cu}$, estuary, heavy metal, mangrove, uptake

\section{Introduction}

Surabaya East Coast region has a ecosystem mangrove forest. The Many species of mangrove can grow well at the mangrove forest. This area has high levels of salinity [1]. Mangroves are perennial woody plants grown in tropical and sub-tropical inter-tidal zones [2]. The distance of Wonorejo forest was 10 - 20 meters from the estuary [2]. River mouth area Wonorejo has various types of mangroves. Type mangroves that are around the Wonorejo River, among others types of Avicennia marina, Avicennia alba, Excoecaria

*Corresponding author: harminsulis@gmail.com, harmin st@its.ac.id 
agalocha, Avicennia officinallis [3]. Mangroves have a tolerance high against heavy metals. Heavy metal accumulation occurs on the roots, stems and leaves of mangroves [4]. Generally, heavy metal pollution in mangrove areas can be caused from urban waste, agricultural waste, effluent Wastewater Treatment Plants (WWTP), industrial effluent waste, use of ships and chemical spills [5].

According to Mulyadi et al., (2009) [6], Cu concentration was 3,186 mg/L at Wonorejo River estuary in 2009. Based on sampling that was conducted in 2016, the $\mathrm{Cu}$ concentration was $22 \mathrm{mg} / \mathrm{kg}$ in sediment at the Wonorejo River estuary. It indicated that $\mathrm{Cu}$ concentration increased. $\mathrm{Cu}$ is included in the essential metal group. $\mathrm{Cu}$ is needed by organisms as a coenzyme in the body's metabolic processes in low levels. However, it can be toxic if the $\mathrm{Cu}$ concentration in high levels [7].

The aim of this research was to determine the potency of $\mathrm{Cu}$ accumulation by Avicennia marina that was grown for ten years at Eco-forest at Wonorejo Estuary.

\section{Materials and Methods}

\subsection{Sampling Location}

Sampling locations were shown in Fig 1 at Eco-forst at Wonorejo Estuary, Surabaya. The sampling activities were carried using a Transect quadrat sampling method due to the Transect quadrat sampling method was suitable. The dimension of one quadrant was $10 \mathrm{~m} \mathrm{x}$ 10m. Sampling point determinations were conducted using a GPSmap 76CSx (Garmin, USA).

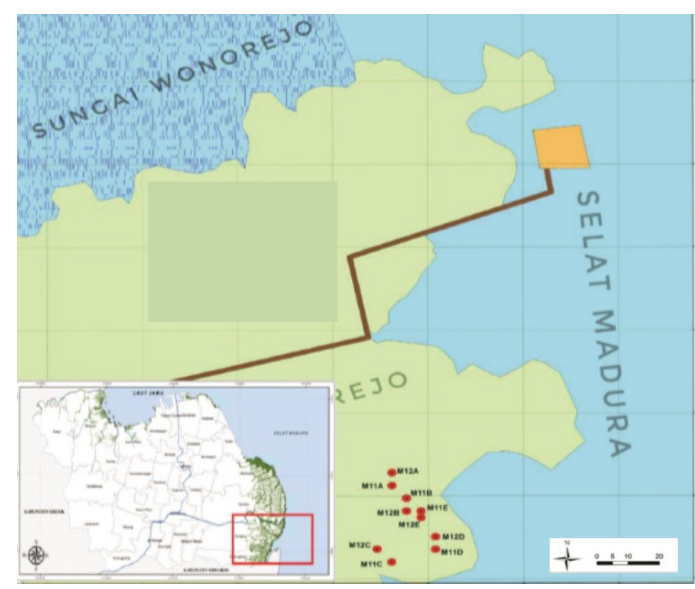

Fig. 1. Sampling Location.

There were ten points of location sampling, namely M11A, M12A, M11B, M12B, M13A, M13B, M11D, M12D, M11E dan M12E. Sampling activities were conducted at the morning time due to sea water level was low enough at that time for sediment sampling. According to Usman \& Mohamed's (2009) methods [8], sediment samplings were carried out by random sampling with a depth of $0-30 \mathrm{~cm}$. Root samplings were carried out using a manual drill. All samples were stored in an icebox at $4^{\circ} \mathrm{C}$. After then, all samples were taken to the Environmental Remediation Laboratory, Department of Environmental Engineering, Institut Teknologi Sepuluh Nopember (ITS) for further analysis. 


\subsection{Parameter Analysis}

Sediment and mangrove root samples were first prepared before being analyzed using an atomic absorption spectrophotometer (AAS). The AAS was used to measure the concentration of $\mathrm{Cu}$ in sediment and A. marina roots. The model of AAS was a Rayleigh WFX 210 (China) at Department of Chemical Engineering, ITS.

First, samples of $A$. marina roots were dried at $105^{\circ} \mathrm{C}$ for $24 \mathrm{~h}$. After that, the dried root samples, were extracted using a modified wet digestion method procedure based on Titah et al. (2013) [9]. Meanwhile, the sediment extraction was conducted using EPA method 3050B (1996) [10].

\subsection{Determination of Bioconcentration Factor (BCF)}

The Bioconcentration Factor (BCF) or Biological Accumulation Coefficient (BAC) calculation [11] was used to determine the ability of the plants to uptake and accumulate some heavy metal from the media [12]. The determination for BAC was based on the following equation [8]. The results of the determination of BCF were matched with categories of plants (Table 1) to classify which plants are hyperaccumulator plants or otherwise [11].

$$
B C F=\frac{C_{\text {roots }}}{C_{\text {media }}}
$$

Table 1. Category of BCF

\begin{tabular}{lc}
\hline \multicolumn{1}{c}{ Category } & Range \\
\hline High accumulator plants & $1-10$ \\
Moderate accumulator plants & $0.1-1$ \\
Low accumulator plants & $0.01-0.1$ \\
Non accumulator plants & $<0.01$ \\
\hline
\end{tabular}

\section{Results and Discussions}

Fig. 2 showed the concentration of $\mathrm{Cu}$ in sediment were $27 \mathrm{mg} / \mathrm{kg}$ until to $150 \mathrm{mg} / \mathrm{kg}$. Based on Interim sediment quality guidelines (ISQGs) [13], the limit of $\mathrm{Cu}$ concentration for $\mathrm{Cu}$ contaminated area was $18.7 \mathrm{mg} / \mathrm{kg}$. Meanwhile, according to EPA sediment quality standard [14], a non polluted area was below $25 \mathrm{mg} / \mathrm{kg}$, a range for $\mathrm{Cu}$ slightly polluted area were $25-50 \mathrm{mg} / \mathrm{kg}$ and concentration value for $\mathrm{Cu}$ severely polluted area was upper than $50 \mathrm{mg} / \mathrm{kg}$. According to Pollution Control Department of Thailand, the limit of $\mathrm{Cu}$ concentration for $\mathrm{Cu}$ polluted area was below $16 \mathrm{mg} / \mathrm{kg}$ [15].

Based on those standard, $\mathrm{Cu}$ concentration of sediment at 10 points of sampling location was shown variation of results. However, according to three standards that were not applied in this country, the condition was categorized as polluted area. 


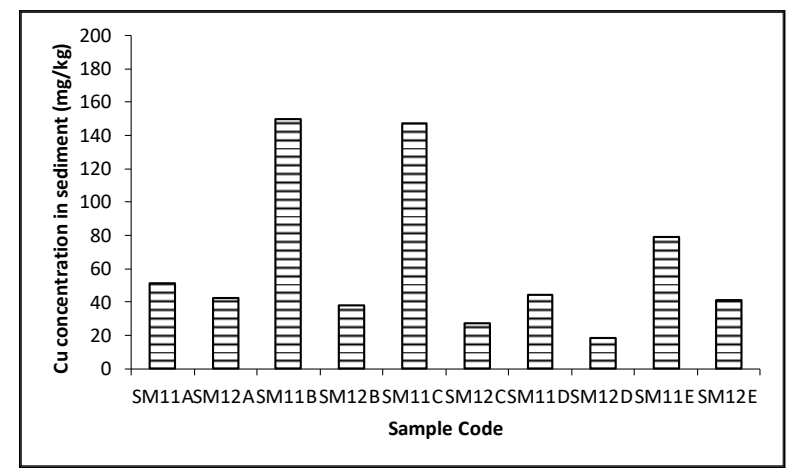

Fig. 2. Concentration of $\mathrm{Cu}$ in sediment at all points of sampling locations

Fig. 3 showed the concentration of $\mathrm{Cu}$ in roots of $A$. marina was $53 \mathrm{mg} / \mathrm{kg}$ until to 128 $\mathrm{mg} / \mathrm{kg}$. It indicating that $A$. marina could uptake $\mathrm{Cu}$ and accumulate it in their roots. Overall, the concentrations of heavy metals were higher in plant roots as compared to sediment samples. According to Almahasheer et. al (2014) [16], grey mangrove or $A$. Marina could absorb and accumulate higher quantities of many heavy metals such as $\mathrm{Cu}$, $\mathrm{Fe}, \mathrm{Mn}, \mathrm{Zn}, \mathrm{B}, \mathrm{Ni}, \mathrm{Pb}$ and $\mathrm{Cd}$. Avicennia marina was found to be highly tolerant to the metals applied. Copper was accumulated in root tissue in a linear relationship at lower sediment concentrations, but at concentrations of $200 \mu \mathrm{g} / \mathrm{g}$ and higher, no further increases in root $\mathrm{Cu}$ levels occurred [17].

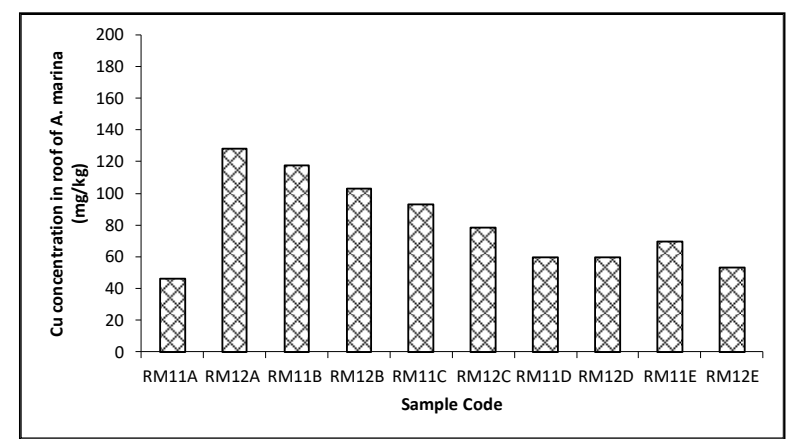

Fig. 3. Concentration of $\mathrm{Cu}$ in roof of $A$. marina at all points of sampling locations

Fig. 4 depicted the value of BCF were calculated based on equation 1. Based on Fig. 4, the $\mathrm{BCF}$ value of $A$. marina on $\mathrm{Cu}$ were 0.91 to 3.22 in sediment. However, $90 \%$ of those $\mathrm{BCF}$ value showed the $\mathrm{BCF}$ value $>1$. It indicated that $A$ marina can uptake, accumulate and has potential as a hypercummulator $\mathrm{Cu}$ plant. According to Usman et al. (2013) [18], $\mathrm{BCF}$ on $A$. marina for heavy metals $(\mathrm{Cu}, \mathrm{Cd}, \mathrm{Ni}, \mathrm{Pb}, \mathrm{Zn}$ and $\mathrm{Cr}$ ) in the mangrove for surface sediments obtained values were too high $(>1)$. 


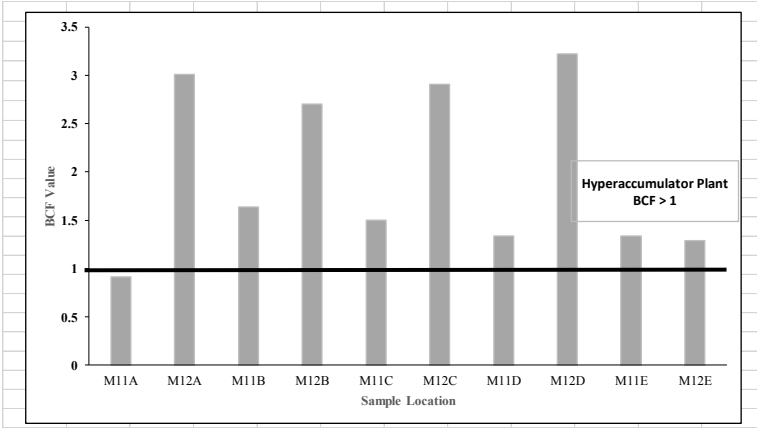

Fig. 4. $\mathrm{BCF}$ value of $\mathrm{A}$. marina on $\mathrm{Cu}$ accumulation in sediment

\section{Conclusions}

Based on data, the range of $\mathrm{Cu}$ concentration at sediment of Wonorejo coastal were 27 $\mathrm{mg} / \mathrm{kg}$ until to $150 \mathrm{mg} / \mathrm{kg}$. The concentration of $\mathrm{Cu}$ in roots of $A$. marina were $53 \mathrm{mg} / \mathrm{kg}$ until to $128 \mathrm{mg} / \mathrm{kg}$. The BCF values on A. marina in sediment were 0.91 to 3.22 . Meanwhile, all of BCF value in sediment showed value $>1$. Based on the BCF value, it indicated that $A$. marina was a hyperacumulator species for heavy metals of $\mathrm{Cu}$. Mangrove A. marina has potentially to be used in $\mathrm{Cu}$ phytoremediation at coastal area.

\section{Acknowledgement}

The author would like to thank Kementerian Riset dan Teknologi/ Badan Riset dan Inovasi Nasional through scheme of Penelitian Dasar Unggulan Perguruan Tinggi - first year research, PDUPT 2020 for funding this research with No of contract, 3/E1/KP.PTNBH/2020, and No of amendment contract, 3/AMD/E1/KP.PTNBH/2020, and No. 1172/PKS/ITS/2020.

\section{References}

1. Arisandi. Mangrove Jenis Api-api (Avicennia marina) Alternatif Pengendalian Logam Berat Pesisir. (2001)

2. H. Adiwijaya. Jurnal Ilmu Teknik Lingkungan. (2008)

3. Badan Lingkungan Hidup Koata Surabaya. Surabaya. (2012)

4. G.R. MacFarlane, and M.D. Burchett. Mar. Pollut. Bull. 42(3), 233-240, (2001).

5. E.C. Peters,N.J. Gassman, J.C. Firman, R.H. Richmond, E.A. Environ Toxicol Chem 16, 12-40. (1997)

6. E, Mulyadi, R. Laksmono, D. Aprianti. Fungsi Mangrove Sebagai Pengendali Pencemar Logam Berat. Jurnal Ilmiah Teknik Lingkungan 1. (2009)

7. E. Rochayatun, M.T. Kaisupy, A. Rozak. Jurnal Makara Sains 10, 1: 35-40. (2006)

8. A.R.A Usman, H.M. Mohamed. Chemosphar, 76: 893-899. (2009)

9. H.S. Titah, S.R.S. Abdullah, I. Mushrifah, N. Anuar, H. Basri, and M. Mukhlisin. Ecological Engineering. 58,303-313. (2013)

10. EPA. Method 3050b acid digestion of sediments, sludges, and soils. (1996)

11. C.L. Bini, L. Gentili,B. Maleci, O.Vaselli. Annexed tocontaminated soil prost. INRA, Paris. (1995).

12. M. Idris, S.R.S. Abdullah, H.S. Titah, M.T. Latif, A.R. Abasa, A.K. Husin, R.T. Hanima, R. Ayub. Journal of Environmental Science and Management 19(1): 27-36. (2016) 
13. Canadian Council of Ministers of the Environment. Canadian Sediment Quality Guidelines for the Protection of Aquatic Life. (2001)

14. B.T. Suny, A.H. Sulaiman, A. Monazami., Salleh, A. Assessment of Sediment Quality Accorfing to Heavy Metal Status in the West Port of Malaysia 2011)

15. E. Wangcharoenrung. Pollution Control Department Thailand. (2015)

16. H.B. Almahasheer, W.A. Al-Taisan, M.K. Mohamed. Journal of Agricultural Science, 6(1),137-140. (2014)

17. G.R. MacFarlane, and M.D. Burchett. Marine Environmental Research, 54(1), 65-84. (2002)

18. A.R. Usman, R.S.Alkredaa, M.I. Al-Wabel. Ecotoxicol Environ Saf. 97,263-70. (2013) 